Monika Struck-Peregończyk, Olga Kurek-Ochmańska Wyższa Szkoła Informatyki i Zarządzania, Rzeszów

\title{
Wizerunek osób niepełnosprawnych w polskiej prasie opiniotwórczej na przykładzie tygodnika "Polityka" w latach 1997-2016
}

DOI: http://dx.doi.org/10.18778/1733-8069.14.3.04

Abstrakt Celem artykułu jest prezentacja wyników przeprowadzonej analizy treści artykułów publikowanych na temat osób niepełnosprawnych i zjawiska niepełnosprawności w tygodnikach opiniotwórczych na przykładzie „Polityki”. Niniejszy artykuł jest próbą nakreślenia wizerunku osób niepełnosprawnych kreowanego w owym tytule. Głównymi kategoriami wziętymi pod uwagę przy analizie były: role społeczne i zawodowe osób niepełnosprawnych będących bohaterami artykułów; próba skatalogowania tematyki; język, jakim opisywano zjawisko niepełnoprawności oraz odniesienie poruszanych wątków do aktualnych wydarzeń i trendów. W artykule przyjrzano się również ogólnym tendencjom w przedstawianiu osób niepełnosprawnych $w$ mediach masowych oraz przybliżono różne podejścia teoretyczne w wyjaśnianiu roli mediów w kreowaniu postaw względem grup społecznych.

Słowa kluczowe wizerunek, niepełnosprawność, prasa, oddziaływanie mediów

\section{Monika Struck-Peregończyk, doktor nauk spo-} łecznych w zakresie nauk o polityce, specjalność: polityka społeczna. Adiunkt w Zakładzie Polityki Publicznej Wyższej Szkoły Informatyki i Zarządzania z siedzibą w Rzeszowie, Jej zainteresowania naukowe koncentrują się wokół polityki społecznej, ze szczególnym uwzględnieniem sytuacji osób niepełnosprawnych, ich aktywności zawodowej i szans edukacyjnych

\section{Adres kontaktowy:}

Wyższa Szkoła Informatyki i Zarządzania z siedzibą

w Rzeszowie

ul. Sucharskiego 2, 35-235 Rzeszów

e-mail: mstruck@wsiz.rzeszow.p
Olga Kurek-Ochmańska, doktor nauk społecznych w zakresie nauk o polityce. Adiunkt w Zakładzie Badań nad Szkolnictwem Wyższym i stały wspó́tpracownik Katedry Mediów, Dziennikarstwa i Komunikacji Społecznej Wyższej Szkoły Informatyki i Zarządzania z siedzibą w Rzeszowie. Jej zainteresowania badawcze koncentrują się wokół: wizerunku osób i instytucji, społecznego i kulturowego oddziaływania mediów, ksztattowania opinii publicznej, polskiego rynku medialnego oraz prawnych, organizacyjnych i ustrojowych uwarunkowań szkolnictwa wyższego.

\section{Adres kontaktowy:}

Wyższa Szkoła Informatyki i Zarządzania z siedzibą w Rzeszowie ul. Sucharskiego 2, 35-235 Rzeszów e-mail: okurek@wsiz.rzeszow.pl
W

społeczeństwa informacyjnego i wszechobecnej mediatyzacji życia społecznego media masowe spełniają wielorakie funkcje. Oprócz tak oczywistych jak informacyjna, edukacyjna czy rozrywkowa media masowe są areną do debaty i dyskusji na tematy ważne publicznie, czyli kształtują nasze opinie. Mają zatem wpływ na nasze postawy, w tym również względem osób niepełnosprawnych.

Ze względu na poruszony problem badawczy koniecznym jest doprecyzowanie terminu „wizerunek". Do nauki pojęcie image wprowadził Walter Lippmann (1922) (Tabernacka, Szadok-Bratuń 2012). Za polskim "Słownikiem wyrazów obcych” wizerunek „to obraz postaci stworzony na podstawie jej działalności zawodowej, cech osobistych lub obraz, oblicze, charakter czegoś" (Sobol 1996: 462). Słownik języka angielskiego podaje natomiast, iż image to po pierwsze „a mental picture or idea of sb/sth", czyli obraz lub wyobrażenie o kimś lub czymś; a po drugie „a general impression that a person or an organization gives to the public", czyli ogólne wrażenie, jakie osoba lub organizacja robi na opinii publicznej (Stownik Oxford Wordpower 2002: 388). Leksykon public relations stwierdza, że „wizerunek to subiektywne wyobrażenie na temat określonej organizacji, firmy, produktu, usługi, osoby, które powstaje w umysłach ludzi" (Tworzydło, Olędzki, Trochimiuk 2009: 174). Jak zatem powstaje owo wyobrażenie?

W świetle koncepcji poznawczej jednostka jako podmiot własnej aktywności przyjmuje wobec otaczającego świata postawę badacza, to znaczy zbiera informacje płynące $\mathrm{z}$ otoczenia, zapisuje je $\mathrm{w}$ pamięci, formułuje sądy wyjaśniające zarejestrowane zjawiska, a potem sprawdza je w rzeczywistości, tworząc tak zwane konstrukty poznawcze, czyli informacje o sobie i otaczającym świecie. Jednostka „tworzy indywidualny system konstruktów, różniący się od systemów innych ludzi poziomem złożoności, abstrakcji i plastyczności (zależnym od poziomu intelektualnego i cech demograficzno-społecznych)" (Wojciszke 2002: 21). Ponieważ ludzie nie są percepcyjnie zdolni, aby przetwarzać całą oddziałująca na nich informację społeczną, stosują tak zwaną oszczędność poznawczą, czyli „uczą się stosować efektywne uproszczenia myślowe i praktyczne reguły zdrowo rozsądkowe, które pomagają im zrozumieć rzeczywistość społeczną" (Aronson, Wilson, Akert 1997: 132). Ową oszczędność poznawczą Susan Fiske i Shelley Taylor nazywają „skąpstwem poznawczym", czyli zbiorem taktyk, które upraszczają złożone problemy poprzez na przykład ignorowanie niektórych informacji celem redukcji dysonansu poznawczego (Piber-Dąbrowska, Sędek 2006). Sytuacja taka może prowadzić do poważnych błędów, uprzedzeń i stereotypów zwłaszcza wtedy, gdy zignorowana zostanie jakaś ważna informacja (Kossowska 2006). Świadomość stosowania przez ludzi oszczędności poznawczych jest zatem bardzo istotna z punktu widzenia zagadnienia wizerunku, bo schematy (m.in. efekt pierwszeństwa, świeżości, uporczywości, heurystyki dostępności, zakotwiczenia, reprezentatywności) działaja jak filtry, które odsiewają informacje sprzeczne, niespójne, dostarczają ludziom wskazówek dotyczących ich opinii i działania (Falkowski, Tyszka 2006).

Wspomniany już W. Lippmann w pracy pod tytułem „Public Opinion” wskazał, że nieuniknione są rozbieżności pomiędzy światem zewnętrznym 
a obrazem w naszych głowach (Baran, Davis 2007: 99). Tak narodziła się pierwsza definicja stereotypu akcentująca, że owe pictures in our heads są reakcją na bodźce ze świata zewnętrznego i ich swoistym przetworzeniem w umyśle człowieka (Anusiewicz, Bartmiński 1998). Tak stworzone konstrukcje myślowe zawierają pewne uproszczone przeświadczenie dotyczące różnych zjawisk społecznych. O tym, w jaki sposób media masowe tworzą i podtrzymują stereotypy różnych grup społecznych, mówi teoria stereotypizacji mediów. Kiedy środki masowego przekazu ukazują pewne kategorie ludzi, akcentując ich negatywne cechy, a pomijają pozytywne, a dodatkowo takie portrety potwierdzane są w różnych mediach, wówczas u odbiorcy dochodzi do zakorzenienia takiego stereotypowego portretu. Oddziaływanie to jest tym mocniejsze, im mniejszy kontakt osobisty z daną kategorią osób ma odbiorca, a im częstszy tylko z przekazem medialnym (Goban-Klas 2008). Jako że mniej niż połowa Polaków ma osoby niepełnosprawne wśród swoich znajomych lub przyjaciół (CBOS 2007, Ruść 2007), media masowe stanowią ważne źródło wiedzy o osobach niepełnosprawnych i ich problemach.

\section{Wizerunek osób niepełnosprawnych w mediach}

Środki masowego przekazu, a w szczególności media o charakterze opiniotwórczym, jakim jest tygodnik społeczno-polityczny „Polityka”, mogą mieć niebagatelny wpływ na kreowanie wizerunku osób niepełnosprawnych, ponieważ swymi publikacjami na ich temat biorą udział w procesie kształtowania postaw swych czytelników. Media masowe ${ }^{1}$ często jednak podchodzą do kwestii niepełnosprawności bardzo powierzchownie, powielając i utrwalając istniejące stereotypy. Jednymi z pierwszych i najważniejszych badań dotyczących wizerunku osób niepełnosprawnych w mediach był brytyjski raport z 1992 roku, w którym Colin Barnes wyróżnił podstawowe typy stereotypów powielanych przez media. Były to: prezentowanie osoby z niepełnosprawnością jako godnej pożałowania i żałosnej, przedmiotu przemocy, groźnej i złej, tworzącej nastrój i osobliwość, „superkaleki”, przedmiotu drwin, najgorszego i jedynego wroga samej siebie, ciężaru dla społeczeństwa, seksualnie nienormalnej, niezdolnej do pełnego udziału w życiu społeczeństwa (Barnes 1992). W mediach możemy się też natknąć na przedstawienie osób niepełnosprawnych jako „normalnych”, „Zwyczajnych” ludzi, których niepełnosprawność jest tylko jedną z cech. Zdaniem Barnesa nadmierne eksponowanie „Zwyczajności” i pomijanie aspektu barier społecznych, na jakie napotykają osoby niepełnosprawne, może jednak prowadzić do przekonania, iż nie potrzebują one wsparcia i nie ma potrzeby zmian w polityce społecznej i nastawieniu społeczeństwa wobec nich (Barnes 1992).

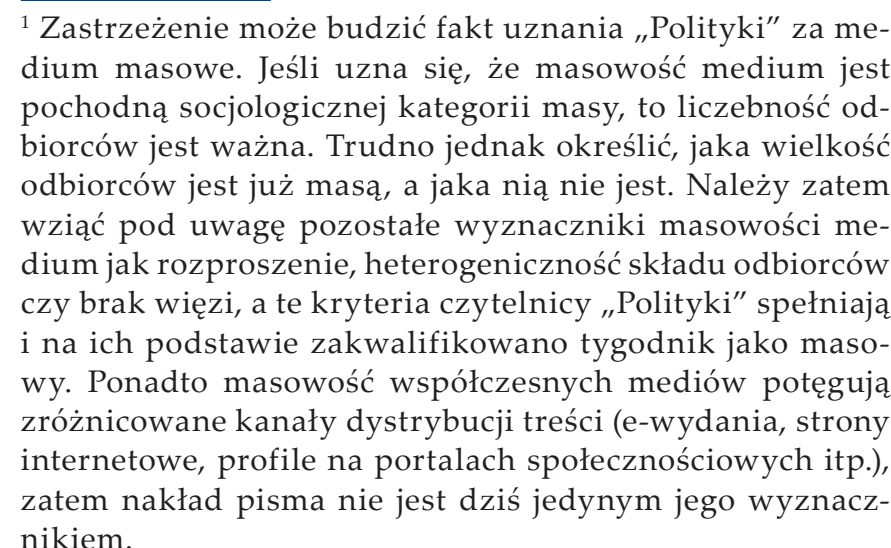

"Zastrzeżenie może budzić fakt uznania „Polityki” za me-
dium masowe. Jeśli uzna się, że masowość medium jes pochodną socjologicznej kategorii masy, to liczebność odbor jest wazna. Trudno jednak okreslic, jaka wielkos wziąc pod uwagę pozostałe wyznaczniki masowości meczy brak wiezi, a te kryteria czytelnicy "Polityki" spełniaja zrożnicowane kanały dystrybucji treści (e-wydania, strony nikiem.
Systematyzacji sposobów przedstawiania osób niepełnosprawnych w mediach podjął się także John Clogston (1990; 1993), który wyróżnił pięć modeli. Trzy to modele "tradycyjne", to jest przedstawiające niepełnosprawność jako "tragedię osobista": model patologii społecznej (osoby niepełnosprawne jako pokrzywdzone przez los i zależne od innych), model medyczny (niepełnosprawność jako choroba lub dysfunkcja), model "superkaleki” („tragiczny, lecz dzielny"). Dwa kolejne modele Clogston scharakteryzował jako "progresywne", to jest przedstawiające osoby niepełnosprawne jako aktywnych członków społeczeństwa: model praw mniejszości I praw obywatelskich (osoby niepełnosprawne jako mające prawa i mogące ich dochodzić) oraz model pluralizmu kulturowego (osoby niepełnosprawne przedstawiane bez podkreślania ich ograniczeń sprawności). Katalog modeli Clogstona został następnie rozszerzony przez Beth Haller (1999; 2000), która dodała jeszcze trzy kategorie: model biznesowy (udogodnienia dla osób niepełnosprawnych jako zbyt kosztowne), model prawny (możliwość dochodzenia swoich praw przez osoby niepełnosprawne jedynie na drodze sądowej) oraz model konsumencki (osoby niepełnosprawne jako niewykorzystana grupa konsumentów).

Polskie badania dotyczące wizerunku osób niepełnosprawnych $\mathrm{w}$ mediach wskazują na to, iż środki masowego przekazu najczęściej odwołują się do dwóch sposobów przedstawiania osób niepełnosprawnych: jako nieszczęśliwych, niesamodzielnych, wymagających pomocy innych (,ofiary") lub tragicznych bohaterów dokonujących niezwykłych czynów „pomimo” swojej niepełnosprawności („,superkaleki”) (Ruść 2007; Rozmus 2012). Może być to postrzegane jako przejaw dyskursu przemocy symbolicznej, polegającego na pomijaniu niektórych tematów, upraszczaniu omawianych kwestii, przesadnym eksponowaniu ograniczeń sprawności oraz paternalistycznym podejściu do opisywanych osób (Niedbalski 2015). Przedstawianie osób niepełnosprawnych w sposób wzbudzający emocje czy sensację jest także dyktowane ekonomicznymi kryteriami podnoszenia oglądalności/czytelnictwa/słuchalności - media powielają uproszczone schematy po to, by „szybko (i najczęściej na krótko) przyciągnąć masowego widza" (Rozmus 2012: 117).

\section{Nota metodologiczna}

W niniejszym artykule podjęto próbę opisu wizerunku osób niepełnosprawnych kreowanego przez polskie tygodniki opiniotwórcze. Prasa opiniotwórcza kształtuje postawy swych czytelników, cytowana jest przez inne media, dziennikarzy i polityków. Stanowi ważny segment rynku prasowego, który swym autorytetem tworzy, upowszechnia, modyfikuje i zakorzenia opinie i postawy zarówno w sferze poglądów politycznych, jak i społecznych. Ma zatem niebagatelny wpływ nie tylko na to, o czym myślą jej odbiorcy, ale też na to, jak myślą i oceniają otaczającą ich rzeczywistość.

Spośród kilkunastu tygodników o tematyce społeczno-polityczno-ekonomicznej zdecydowano się na analizę tygodnika „Polityka”. Argumenty uzasadniające wybór jednostki analizy:

- „Polityka” to najstarszy tygodnik opiniotwórcy ukazujący się od 1957 roku, 
- „Polityka” jest w czołówce liderów sprzedaży i czytelnictwa wśród polskich tygodników opiniotwórczych, zajmując drugie miejsce². Nie zdecydowano się na analizę tygodnika "Newsweek", który zajmuje pierwsze miejsce, ze względu na stosunkowo krótki czas od kiedy tygodnik ten pojawił się polskim rynku prasowym, niepokrywający się z analizowanym okresem 1997-2016,

- Dokonując wstępnej kwerendy zasobów bibliotecznych, zauważono, że „Polityka” publikuje znacząco więcej artykułów o tematyce niepełnosprawności niż pozostałe tygodniki opiniotwórcze, jak na przykład „Wprost”, „Tygodnik Powszechny” czy „Duży Format”,

- Wśród czytelników ${ }^{3}$ „Polityki” przeważają osoby z wyższym wykształceniem $-85 \%$. Większość czytelników należy do osób dobrze sytuowanych ${ }^{4}$. Nieco ponad jedna trzecia czytelników „Polityki” prowadzi własne działalności gospodarcze. Na podstawie tak scharakteryzowanego profilu demograficzno-społecznego czytelników „Polityki" można pokusić się o wniosek, że mimo iż stanowią mniejszość w sensie ilościowym/ powszechnym, są elitą i mają wpływ na

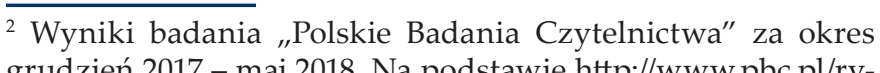
grudzień 2017 - maj 2018. Na podstawie http://www.pbc.pl/rynek-prasowy/raporty-pbc/tygodniki/ [dostęp 31.07.2018 r.].]

3 Wyniki ankiety redakcyjnej przeprowadzonej w 2014 roku
${ }_{\text {wśród } 15000 \text { czytelników. Na podstawie https://wwww polityka. }}$ wisrod 15000 czytelników. Na podstawie https://www.polityka. pl/tygodnikpolityka/spoleczenstwo/159727,
tyki-o-polityce.read [dostęp 31.07.2018 r.].

${ }^{4}$ Aż $78,6 \%$ respondentów zadeklarowało, że ich sytuacia materialna pozwala na realizację wszystkich potrzeb - na podstawie: http:// na pozwala na realizacje wszystkich potrzeb - na podstawie: http://
www.polityka.pl/tygodnikpolityka/spoleczenstwo/1597279,1,czytelnicy-polityki-o-polityce.read [dostęp 26.10.2017 r.]. kreowanie opinii większości poprzez swoja liderską pozycję. Wniosek ten oparty jest na założeniach teorii dwustopniowego przepływu informacji i idei, które podkreślają, że informacje, interpretacje faktów, komentarze czy idee rozpowszechniane przez media docierają najpierw do osób aktywnych medialnie (tzw. liderów opinii), a następnie są przez nie przekazywane osobom mniej aktywnym $\mathrm{w}$ najbliższym otoczeniu. Konceptualizując badania, założono zatem, że czytelnicy „Polityki" stanowią w swoim otoczeniu funkcje liderów opinii publicznej.

Za podstawową jednostkę analizy przyjęto artykuł, to jest reportaż, komentarz, felieton, esej, wstępniak, artykuł publicystyczny lub wywiad, który w swej treści - całościowo lub fragmentarycznie poświęcony był zjawisku niepełnosprawności i zagadnieniom związanym z osobami niepełnosprawnymi. Artykuły, które poddano analizie, kodowano, biorąc pod uwagę następujące kryteria, tak zwane kategorie analityczne:

- role społeczne osób niepełnosprawnych będących bohaterami artykułu,

- sposób prezentowania aktywności zawodowej osób niepełnosprawnych będących bohaterami artykułu,

- sposób prezentowania aktywności społecznej osób niepełnosprawnych będących bohaterami artykułu,

- sposób prezentowania aktywności obywatelskiej osób niepełnosprawnych będących bohaterami artykułu,

- wydźwięk emocjonalny tekstu,
- język, jakim opisuje się w artykule osoby niepełnosprawne i zjawisko niepełnosprawności,

- stopień odzwierciedlenia $\mathrm{w}$ artykule aktualnych wydarzeń politycznych, społecznych, gospodarczych mających bezpośredni lub pośredni wpływ na życie i funkcjonowanie osób niepełnosprawnych.

Analizie nie poddawano materiałów wizualnych, to jest fotografii, tabel, wykresów, ilustracji, a jedynie samą warstwę słowną. Zastosowano zatem technikę analizy treści, a nie analizy zawartości mediów. Uwzględniono, poza cyklicznymi wydaniami, również numery specjalne oraz dodatki. Przy dogłębnej jakościowej analizie treści wzięto pod uwagę teksty z roku 1997, 2007 oraz 2016, tak by spróbować uchwycić zmiany w sposobie przedstawienia wizerunku osób niepełnosprawnych w ciągu 20 lat, które minęły od uchwalenia Ustawy z dnia 27 sierpnia 1997 roku o rehabilitacji zawodowej i społecznej oraz zatrudnianiu osób niepełnosprawnych. Ustawa ta wprowadzała wiele istotnych rozwiązań dotyczących rehabilitacji społecznej i zawodowej, rozszerzając znacznie zapisy ustawy z 1991 r. ${ }^{5}$ - między innymi modyfikowała zasady kwotowego systemu wspierania zatrudnienia osób niepełnosprawnych oraz wprowadzała nowy system orzekania o niepełnosprawności. Zakładano więc, iż w roku 1997 w związku z uchwaleniem ustawy, a także uchwalonej w tym czasie Karty Praw Osób Niepełnosprawnych, mogło ukazać się stosunkowo więcej tekstów dotyczących osób niepełnosprawnych oraz rozwiązań i zaleceń proponowanych $\mathrm{w}$ obu doku-

$\overline{{ }^{5} \text { Ustawa z dnia } 9}$ maja 1991 r. o zatrudnieniu i rehabilitacji zawodowej osób niepełnosprawnych (Dz.U. z 1991 r., nr 46 poz. mentach. W 2007 roku, w związku z rozpoczęciem wielu projektów aktywizacyjnych finansowanych w ramach Programu Operacyjnego Kapitał Ludzki (PO KL), mogła się toczyć na łamach tygodnika ożywiona dyskusja na tematy związane z zatrudnianiem osób niepełnosprawnych.

Celem uszczegółowienia problemu badawczego na etapie konceptualizacji badania postawiono następujące pytania badawcze:

- Jaki wizerunek osób niepełnosprawnych kreuje tygodnik opiniotwórczy „Polityka”? Czy ewoluował on na przestrzeni 20 lat? Czy wizerunek ten bliższy jest modelom ,tradycyjnym" czy „progresywnym” (w ujęciu J. Clogstona)?

- Czy treść artykułów była odzwierciedleniem aktualnych wydarzeń dotyczących życia osób niepełnosprawnych (np. wprowadzenia przepisów prawnych, nowych rozwiązań, aktualnych zjawisk społeczno-politycznych)?

- W jakich rolach społecznych zostały przedstawione osoby niepełnosprawne będące bohaterami tekstów w tygodniku opiniotwórczym „Polityka”?

- Jak prezentowana jest aktywność zawodowa, społeczna, obywatelska osób niepełnosprawnych?

- Jaki jest wydźwięk tekstów na temat osób niepełnosprawnych w tygodniku opiniotwórczym „Polityka”? Czy wydźwięk ten zmieniał się $\mathrm{w}$ analizowanym okresie? 
- Jaki język dominuje w opisie osób niepełnosprawnych? Czy występują pejoratywne określenia? Jeśli tak, to jaki jest cel i kontekst ich stosowania?

Teza przewodnia badania: Na przestrzeni lat 19972016 wizerunek osób niepełnosprawnych kreowany przez tygodnik „Polityka” ewoluuje od modeli bardziej „tradycyjnych” do modeli "progresywnych”. Teza uzupełniająca badania: Na przestrzeni lat 19972016 ewoluuje język, jakim opisuje się osoby niepełnosprawne i zjawisko niepełnosprawności w tygodniku „Polityka”. Wraz z upływem czasu maleje liczba artykułów mających pejoratywny wydźwięk.

Operacjonalizacja nieostrych pojęć użytych w tezach:

- „Modele tradycyjne” - sposób przedstawienia osób niepełnosprawnych jako „innych", w sposób stygmatyzujący.

Wskaźniki: przedstawienie w artykułach osób niepełnosprawnych jako chorych, biernych i zależnych od innych (model medyczny), pokrzywdzonych przez los i oczekujących pomocy od państwa i społeczeństwa (model patologii społecznej), ludzi dokonujących niezwykłych czynów lub osiągających, "pomimo” swojej niepełnosprawności, coś, co w świecie osób sprawnych byłoby uznane za normalne (model "superkaleki"), jako osoby, których ograniczenia sprawności generują koszty obciążające społeczeństwo i przedsiębiorców (model biznesowy).

- „Modele progresywne” - sposób przedstawienia osób niepełnosprawnych jako mających możliwości i prawa, by brać udział we wszystkich aspektach życia społecznego.

Wskaźniki: przedstawienie w artykułach osób niepełnosprawnych jako członków mniejszości mających prawa i mogących ich dochodzić (model praw mniejszości / praw obywatelskich), jako „zwykłych” ludzi, bez podkreślania ich ograniczeń sprawności (model pluralizmu kulturowego), jako osoby chronione przed dyskryminacją (model prawny) oraz jako niewykorzystaną grupę konsumentów (model konsumencki).

- „Pejoratywny wydźwięk” - przedstawianie osób niepełnosprawnych w negatywnie nacechowanym, niekorzystnym świetle.

Wskaźniki: występowanie słów o charakterze pejoratywnym, jak na przykład upośledzony, inwalida, kaleka, ułomny, sprawny inaczej, niedorozwinięty, idiota, opóźniony, ślepy i tym podobne; akcentowanie negatywnych cech osób niepełnosprawnych; wzbudzanie negatywnych uczuć.

\section{Tematyka artykułów poruszających zagadnienie niepełnosprawności i osób niepełnosprawnych}

Wśród analizowanych tekstów dominują reportaże obrazowo opisujące codzienność osób niepełnosprawnych oraz problemy, z jakimi borykają się ich rodziny. Wśród reportaży z 1997 roku były:

- reportaż na temat seksualności, rodzicielstwa i małżeństw osób niepełnosprawnych intelektualnie („Matki z gorszym mózgiem”),
- fotoreportaż o osobach niepełnosprawnych intelektualnie, grających $\mathrm{w}$ amatorskim teatrze (,Teatr albo nic"),

- reportaż o rodzicach skupionych wokół Fundacji „Daj szansę", wspierającej rodziny z dziećmi z mózgowym porażeniem dziecięcym („Łańcuch pocieszenia”),

- reportaż o rodzicach poszukujących pieniędzy na kosztowną terapię hormonalną dla swoich córek z zespołem Turnera („Kreseczka za miliony").

Tematyka reportaży z 2007 roku przedstawia się następująco:

- fotoreportaż o działalności Fundacji Awangarda, zajmującej się sprzedażą wyrobów artystycznych wytwarzanych przez osoby niepełnosprawne, $w$ tym osoby z niepełnosprawnością intelektualną („Żyrafa na ośmiu nogach”),

- fotoreportaż o psach-przewodnikach jako asystentach codzienności dla osób niepełnosprawnych („Pan na smyczy”),

- reportaż na temat rodziny, w której rodzi się dziecko ze skrajnym wcześniactwem, bez szans na przeżycie, a które jednak rozwija się prawidłowo; rodzice upatrują cudu za sprawą Jana Pawła II; rodzina zamierza adoptować niepełnosprawne dziecko („Życie za życie”),

- reportaż na temat dzieci niewidomych i niedowidzących, które w ramach terapii grupo- wej uczestniczą w seansach filmowych („Prawie kino"),

- fotoreportaż o czterech parach dotkniętych karłowatością („Mały szuka nieba”),

- reportaż na temat metod uczenia dzieci niesłyszących mowy artykułowanej („Głuche słowa”).

W 2016 „Polityka” opublikowała jedynie trzy reportaże, których bohaterami są osoby niepełnosprawne:

- fotoreportaż o specjalistycznych rodzinach zastępczych dla niepełnosprawnych dzieci („,Kocham cię, ty moja matko zastępcza”),

- reportaż-sylwetka o niepełnosprawnym intelektualnie sportowcu, członku kadry Polski w tenisie stołowym („Mentalny”),

- reportaż o poruszającym się na wózku Janie, który startował w odwołanym konkursie Mężczyzna Roku na Wózku 2016 (,Mister”).

Pozostałe artykuły gatunkowo zakwalifikować można jako:

- komentarze - krytyka rozwiązań zaproponowanych w Ustawie z dnia 27 sierpnia 1997 roku o rehabilitacji zawodowej i społecznej oraz zatrudnianiu osób niepełnosprawnych (,Każdy głos na wagę złota" z 1997 roku) oraz komentarz na temat błędnych decyzji politycznych i zaniechań systemowych $\mathrm{w}$ aspekcie niepełnosprawności („Udane niepowodzenia” z 2016 roku), 
- artykuły publicystyczne: na temat lawinowo rosnącej liczby młodych rencistów, krytyka zbyt wczesnego przyznawania rent, afirmacja rehabilitacji jako sposobu na przywrócenie osób niepełnosprawnych na rynek pracy („Będąc młodym rencistą" z 1997 roku); na temat autyzmu („Zobaczyć las” z 2007 roku); na temat chorób rzadkich, kosztów związanych z ich leczeniem, stowarzyszeń, które zrzeszają chorych i ich rodziny („Zapomoga na Pompego" z 2007 roku); na temat zalet telepracy, w tym korzyści z niej dla osób niepełnosprawnych („Telechałupnicy” z 2007 roku); na temat złych standardów leczenia hemofilii w Polsce („Królewska choroba” z 2007 roku); na temat ojców dzieci niepełnosprawnych oraz powodów ich odchodzenia od rodziny w przypadku pojawienia się $w$ rodzinie chorego dziecka („Gdzie ci ojcowie?” z 2016 roku); na temat jakości życia i kosztów leczenia dzieci z wrodzonymi wadami rozwojowymi (,Życie poza życiem" z 2016 roku),

- recenzje - recenzja filmu „Ósmy dzień" poszerzona o analizę innych dzieł kinowych zbudowanych na motywie niepełnosprawności („Debil i jego biznesmen” z 1997 roku),

- opowieść autobiograficzna kobiety, która uległa wypadkowi samochodowemu, w skutek czego porusza się na wózku inwalidzkim („,W snach ciągle chodzę" z 2016 roku).

Łącznie w trzech analizowanych rocznikach „Polityki" opublikowano 24 artykuły poruszające zagadnienie niepełnosprawności i osób niepełno- sprawnych, z czego $7 \mathrm{w} 1997$ roku, $10 \mathrm{w} 2007$ roku i 7 w 2016 roku. Wśród artykułów dominowały reportaże (12) oraz artykuły publicystyczne (7), sporadycznie pojawiały się inne teksty gatunkowo przypisane do publicystyki.

Jednym z głównych celów analizowanych artykułów było pokazanie trudnej sytuacji osób niepełnosprawnych, zarówno związanej z problemami zdrowotnymi (rzadkie choroby, trudności w leczeniu i rehabilitacji), jak i finansowymi (trudności $\mathrm{z}$ finansowaniem leczenia, $\mathrm{z}$ utrzymaniem się $)^{6}$ często bohaterami tego typu tekstów są dzieci ${ }^{7}$. Wydaje się, że celem przyświecającym tego typu tekstom było przekonanie, że osoby niepełnosprawne to grupa wymagająca wsparcia oraz krytyka systemu i działań państwa kierowanych do tej grupy osób. Wskazywane są takie niedociągnięcia jak: brak refundacji leków czy terapii, poziom opieki zdrowotnej znacznie odbiegający od światowych standardów ${ }^{8}$, niewystarczająca opieka instytucjonalna i brak pomocy dla rodzin osób niepełnosprawnych ${ }^{9}$, a także brak wsparcia dla utalentowanych osób niepełnosprawnych - przykład sportowca Marka Chybińskiego, który „nie trenuje bo musi pracować. A musi pracować, bo nie ma na treningi"10. Widoczna jest bezsilność osób niepełnosprawnych i ich rodzin, które zmuszone

6 ",Eańcuch pocieszenia", „Kreseczka za miliony", „,Królewsk choroba", , Zapomoga na Pompego", „Mentalny".

" „Eańcuch pocieszenia”, ,"Kreseczka za miliony", „Królewska choroba”, "Zycie za życie”, „,Kocham cię, ty moja matko zastępcza", , „Życie poza życiem"

8 "Kreseczka za miliony", „Królewska choroba”, ,Zapomoga na Pompego".

"„Łańcuch pocieszenia”, „Zapomoga na Pompego", „Życie poza życiem"

${ }_{10}$ "Mentalny" są dawać sobie radę same: „Rodzice muszą zdobyć sami pieniądze na leczenie swoich córek albo bezsilnie patrzeć jak je Turner degraduje” ${ }^{\prime 11}$; „,walimy głową w mur"12. Mimo iż na przestrzeni 20 lat zmieniły się nieco standardy leczenia i opieki nad osobami niepełnosprawnymi (np. w 1999 r. zaczął być refundowany hormon wzrostu dla chorych na zespół Turnera), liczba tekstów dotykających wyżej wymienionych problemów nie spadła. Wątek krytyki systemu najbardziej rozbudowany został w tekście „Udane niepowodzenia” z 2016 roku, który dotyczy dotychczasowych prób działań państwa na rzecz poprawy sytuacji osób niepełnosprawnych, stwierdzając iż „mimo że wiele debat parlamentarnych pokazało ponadpartyjną zgodę, że osoby z niepełnosprawnościami należy wspierać” wprowadzane reformy są „proste, bazujące na jednym haśle, oparte na polityce interwencyjnej, których efekty są widoczne tu i teraz", zaś polityka wobec niepełnosprawności to przykład „polityki udanego niepowodzenia".

Część z analizowanych tekstów ma za zadanie spełniać funkcję informacyjną - dostarczyć czy telnikowi rzetelnej, czasem wręcz naukowej informacji na temat danego schorzenia czy niepełnosprawności ${ }^{13}$ lub też zmian w prawie ${ }^{14}$, czasem przybiera to postać infografiki z wyróżnionym tekstem. Niektóre teksty podjęły trud obalania mitów związanych z danym schorzeniem (np. stereotypy dotyczące osób z niepełnosprawnością intelektualną, autyzmem czy też

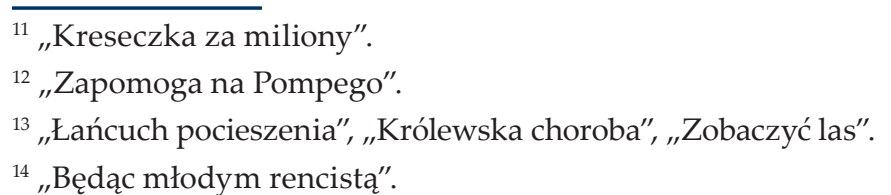

hemofilią $\left.{ }^{15}\right), \mathrm{z}$ postrzeganiem osób niepełnosprawnych przez osoby sprawne ${ }^{16} \mathrm{czy}$ też roli ojca w życiu niepełnosprawnego dziecka ${ }^{17}$. Duża część tekstów ma również na celu przybliżenie czytelnikom nowych rozwiązań dostępnych w leczeniu, rehabilitacji i wsparciu społecznym osób z niepełnosprawnościami, jak na przykład nowoczesna terapia dzieci z porażeniem mózgowym ${ }^{18}$, teatralne warsztaty terapii zajęciowej dla osób z niepełnosprawnością intelektualną ${ }^{19}$, rehabilitacja lecznicza finansowana przez ZUS ${ }^{20}$, pies-asystent dla osób poruszających się na wózku ${ }^{21}$ czy telepraca ${ }^{22}$.

Ważnym celem części analizowanych tekstów jest również wywołanie u czytelnika określonych uczuć. Bardzo często było to współczucie lub litość, szczególnie jeśli bohaterami tekstu były niepełnosprawne dzieci: „Nie mogłam uwierzyć, że w 38-milionowym kraju nie było nikogo, kto pokocha to dziecko. Kocha się obce żółwie, koty, psy"23. Część tekstów, poprzez dosadne porównania i bardzo naturalistyczne opisy, ma zszokować odbiorcę: „wywalają upośledzonego właściciela jak kulawy tapczan”24, „małe, grube (...) z nieforemną szyją w kształcie płetwy, czasem z ostającymi uszami, z szeroko rozstawionymi oczyma (...) płaskie i nieforemne" ${ }^{25}$, „uciekła (...) od tego,

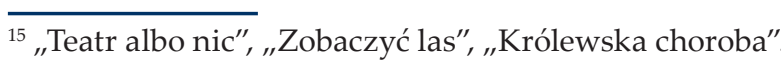
${ }^{16}$ "Debil i jego biznesmen"

${ }^{17}$ "Gdzie ci ojcowie?"

${ }_{18}^{18}$ "Eańcuch pocieszenia".

${ }^{19}$ "Teatr albo nic".

${ }^{20}$ "Będąc młodym rencistą".

${ }^{21}$ "Pan na smyczy".

22 "Telechałupnicy".

${ }^{23}$ "Życie za życie".

${ }^{24}$ "Matki z gorszym mózgiem".

25 "Kreseczka za miliony". 
jak on człapie, jak wkłada spodnie na pieluchę, bo od czasu, gdy spadł z rusztowania, poszły zwieracze dróg moczowych" ${ }^{26}$. W ten sposób wzbudza się też jednak niezdrowe zainteresowanie odmiennością, nawiązujące do dawnych „pokazów osobliwości" - publicznych pokazów osób z widocznymi zniekształceniami ciała popularnych w USA i Europie do początków XX w. (Barnes1992; Ruść 2007).

Wśród analizowanych tekstów były też takie, które miały za zadanie wzruszyć czytelnika ${ }^{27}$, wywołać $\mathrm{w}$ nim przyjazne i cieple uczucia wobec bohaterów ${ }^{28}$, czy wręcz podziw dla tego, w jaki sposób walczą z przeciwnościami losu ${ }^{29}$, czy poświęcają się dla innych - tak jak na przykład rodzice (biologiczni czy zastępczy) niepełnosprawnych dzieci ${ }^{30}$. Sposób prezentowania osób niepełnosprawnych $\mathrm{w}$ analizowanych artykułach jest niejednorodny, wieloaspektowy, o różnym natężeniu emocjonalnym i zróżnicowanym wydźwięku. Chcąc dokonać pewnej kategoryzacji, zdecydowano się na dogłębną analizę następujących aspektów: tematyka tekstów a aktualne wydarzenia społeczno-polityczne i trendy, aktywność zawodowa, aktywność społeczna, seksualność i życie rodzinne, relacje osób niepełnosprawnych $z$ otoczeniem, intencjonalne oddziaływanie tekstów oraz warstwa językowa stosowana do opisu niepełnosprawności i osób niepełnosprawnych. Kolejne podrozdziały rozwijają owe zagadnienia.

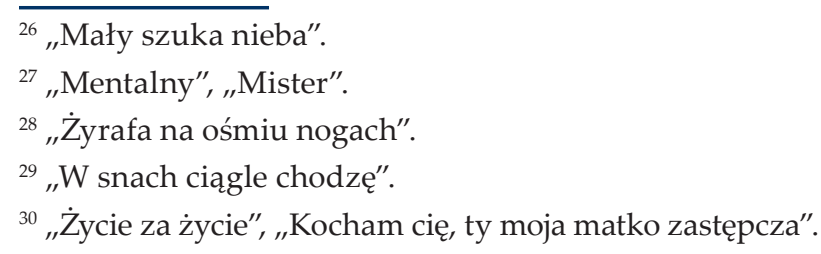

\section{Tematyka analizowanych tekstów a aktualne wydarzenia}

Więcej niż połowa tematów artykułów inspirowana była aktualnymi wydarzeniami dotyczącymi życia osób niepełnosprawnych. Część artykułów była odpowiedzą na wprowadzenie nowych przepisów prawnych (Ustawa z dnia 27 sierpnia 1997 roku o rehabilitacji zawodowej i społecznej oraz zatrudnianiu osób niepełnosprawnych ${ }^{31}$, Ustawa $\mathrm{z}$ dnia 28 czerwca 1996 r. o zmianie niektórych ustaw o zaopatrzeniu emerytalnym i o ubezpieczeniu społecznym ${ }^{32}$, Ustawa z dnia 24 sierpnia 2007 r. o zmianie ustawy - Kodeks pracy oraz niektórych innych ustaw $^{33}$, projekt ustawy antyaborcyjnej z 2016 r. $^{34}$, Ustawa z dnia 4 listopada 2016 r. o wsparciu kobiet w ciąży i rodzin „Za życiem”35). Dziwić może fakt, iż tak ważnej ustawie jak tej z dnia 27 sierpnia 1997 roku o rehabilitacji zawodowej i społecznej oraz zatrudnianiu osób niepełnosprawnych został poświęcony w 1997 roku tylko jeden artykuł, a do tego krótki i bardzo jednostronny komentarz. Brak w nim odniesienia do aktywności zawodowej osób niepełnosprawnych i ich sytuacji na rynku pracy, tekst mówi tylko o sytuacji przedsiębiorców i ma za zadanie przekonać czytelnika, że rozwiązania

$\overline{{ }^{31} \text { Ustawa z dnia } 27}$ sierpnia 1997 roku o rehabilitacji zawodowej i społecznej oraz zatrudnianiu osób niepetnosprawnych,
Dz.U. 2011, Nr 127, poz. 721 z późn. zm. .Każdy głos na wage złota".

${ }^{32}$ Ustawa z dnia 28 czerwca 1996 r. o zmianie niektórych ustaw o zaopatrzeniu emerytalnym i o ubezpieczeniu społecznym Dz.U. 1996, Nr 100, poz. 461, „Będąc młodym rencistą".

${ }^{33}$ Ustawa z dnia 24 sierpnia 2007 r. o zmianie ustawy - Kodeks pracy oraz niektórych innych ustaw, Dz.U. $2007 \mathrm{Nr}$ 181, poz 1288 , „Telechałupnicy".

${ }^{34}$ "Gdzie ci ojcowie?".

${ }^{35}$ Ustawa z dnia 4 listopada 2016 r. o wsparciu kobiet w ciaży i rodzin „Za życiem”, Dz. U. 2016, poz. 1860, „Życie poza ży ciem" i ",Udane niepowodzenia". proponowanie $\mathrm{w}$ nowej ustawie są złe, bo nakładają na przedsiębiorców zbyt duże obciążenia, a ich wprowadzenie to jedynie strategia polityczna partii, mająca na celu zdobycie głosów osób niepełnosprawnych i udowodnienie pozornej wrażliwości społecznej.

Część artykułów nawiązuje też do różnego rodzaju tendencji i aktualnych zjawisk społeczno-politycznych: premiery filmu ${ }^{36}$, powstawania pierwszych hosteli dla osób niepełnosprawnych intelektualnie $^{37}$, braku refundacji leków dla dziewczynek chorych na zespół Turnera ${ }^{38}$, spekulacji na temat związku szczepień z autyzmem ${ }^{39}$, prac nad powołaniem zespołu ds. chorób rzadkich ${ }^{40}$ oraz odwołanego konkursu Mężczyzna Roku na Wózku 2016¹.

\section{Aktywność zawodowa}

Niezmienny od wielu lat niski poziom aktywności zawodowej osób niepełnosprawnych (o wiele niższy niż $\mathrm{w}$ przypadku osób sprawnych ${ }^{42}$ ) wydaje się być nośnym tematem na artykuł opublikowany w opiniotwórczym tygodniku. Jak wynika z analizy tekstów z wybranych lat, temat aktywności zawodowej pojawiał $\mathrm{w}$ ponad połowie analizowanych artykułów, w żadnym z nich nie był on jednak tematem głównym. Nie można także zauważyć

${ }_{36}$ "Debil i jego biznesmen".
${ }^{37}$ "Matki z gorszym mózgiem".
${ }^{38}$ "Kreseczka za miliony".
${ }^{39}$ "Zobaczyć las".
${ }^{40}$ "Zapomoga na Pompego".
${ }^{41}$ "Mister".
${ }^{42}$ Jak wskazują dane BAEL GUS, w 1997 wskaźnik zatrudnie-
nia osób niepetnosprawnych w wieku 16 lat i więcej był trzy-
krotnie niższy niż w przypadku osób sprawnych, w 2007 i 2016
r. - czterokrotnie niższy. Zob. http://www.niepelnosprawni.
gov.pl/p,o1,bael [dostęp 26.10.2017 r.].

nasilenia zainteresowania tą tematyką $\mathrm{w}$ żadnym analizowanym roku. Praca zawodowa - jeśli już jest wspomniana - jest zazwyczaj przedstawiana jako szansa dla osób niepełnosprawnych - na usamodzielnienie, na zarobienie własnych pieniędzy $\mathrm{y}^{43}$, zapełnienie pustki (,W Polsce tylko niewielu niepełnosprawnych ma szansę zamienić «nic» na pracę" $\left.{ }^{\prime \prime 4}\right)$, poczucie, że jest się potrzebnym ${ }^{45}$, na „wyjście do ludzi" ${ }^{\prime \prime 46}$. Część opisywanych osób niepełnosprawnych to osoby ambitne, dobrze wykształcone: Jan, który skończył politologię i myśli o studiach doktoranc$\mathrm{kich}^{47}$, studentka Ania ${ }^{48}$, niesłysząca od urodzenia studentka Justyna ${ }^{49}$, absolwentka AWF Magda ${ }^{50}$. Pokazane są także osoby wykonujące odpowiedzialną czy też wymagającą kwalifikacji pracę: inżynier informatyk pracujący zdalnie, pracownik biurowy w PFRON, księgowy, urzędnik w wydziale ds. osób niepełnosprawnych ${ }^{51}$. W większości przypadków praca wykonywana przez osoby niepełnosprawne to jednakże praca fizyczna, niewymagająca wysokich kwalifikacji (kucharz, szczotkarz, ślusarz, rolnik, pomoc kuchenna ${ }^{52}$ ), często na chronionym rynku pracy (,jjak oni wszyscy" $\left.{ }^{\prime \prime 3}\right)$. Część bohaterów tekstów to osoby pracowite - jak bohater reportażu

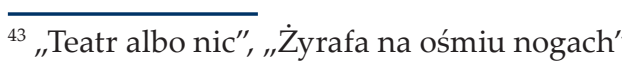

${ }_{44}^{44}$ "Teatr albo nic".

${ }^{45}$ "Żyrafa na ośmiu nogach".

${ }^{46}$ ",W snach ciaggle chodzę".

${ }^{47}$ "Mister".

${ }^{48}$ "Pan na smyczy".

"49 "Głuche słowa".

${ }^{50}$ "W snach ciagle chodze".

${ }^{51}$ "Telechałupnicy", ,"Mały szuka nieba", ,W wnach ciagle chodzee". Można jednak zauważyć, że większość ww. stanowisk znajduje się $\mathrm{w}$ administracji publicznej albo $\mathrm{w}$ III sektorze, co
może sugerować, że osoby niepełnosprawne rzadko odnosza może sugerowac, ze osicy $\mathrm{w}$ przedsiębiorstwach prywatnych sukces jako pracownicy
albo własnych firmach.

52 "Prawie kino" "Mały szuka nieba".

${ }^{53}$ "Matki z gorszym mózgiem". 
„Mentalny": „Pracuje szybko i sprawnie, mówią na niego Maszyna", lubiące swoją pracę - jak określają zajęcia w warsztatach terapii zajęciowej bohaterowie reportażu „Teatr albo nic": „czasem bywają zmęczeni, lecz znoszą to z godnością, ponieważ lubią swoją pracę", odnoszące finansowy sukces: „Włodek nie pracuje w reklamie za mikroskopijne pieniądze, ale za dużą forsę $e^{\prime \prime 54}$.

Kilka tekstów wskazuje też na problem bierności zawodowej osób niepełnosprawnych, wynikającej bądź to z obawy o utratę renty ${ }^{55}$, bądź też ze specyfiki niepełnosprawności, która utrudnia funkcjonowanie w świecie osób sprawnych - szczególnie w przypadku osób z niepełnosprawnością intelektualną, niewidomych, niesłyszących. Osoby niesłyszące zostały w większości przedstawione jako niepracujące, klienci pomocy społecznej, niezaradne, bierne: „Cieszyńska zna środowisko niesłyszących nie tylko z teorii, obserwuje, co dzieje się z absolwentami ośrodka dla niesłyszących, którzy nie mogą znaleźć pracy, utrzymują się z renty. - Nic nie robią. Piją" ${ }^{\prime \prime 6}$.

\section{Aktywność społeczna}

Przechodząc do wątku aktywności społecznej osób niepełnosprawnych, odniesienia do niej można zauważyć $\mathrm{w}$ ponad połowie analizowanych tekstów. W kilku z nich można odnaleźć sylwetki osób niepełnosprawnych aktywnych $\mathrm{w}$ różnych dziedzinach życia: sporcie (Marek Chybiński, bohater reportażu „Mentalny”), sztuce (bohaterowie foto-

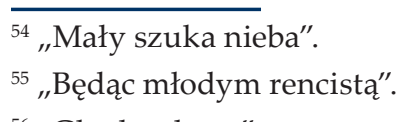

reportażu „Żyrafa na ośmiu nogach”), działalności społecznej (Teresa Matulka, prezes stowarzyszenia działającego na rzecz chorych na mukopolisacharydozę $e^{57}$, Magda Biegańska, prezes stowarzyszenia osób niepełnosprawnych na wózkach ${ }^{58}$ ). Pokazane są też przykłady osób niepełnosprawnych pomagających innym, stanowiących dla nich wzór - wspomniany Marek Chybiński trenujący społecznie dzieci ze swojej gminy. Ewelina Zalewska zdecydowała się na pracę z dziećmi niepełnosprawnymi, by „widziały, że w ich sytuacji można coś jeszcze zrobić z życiem". Sama stara się być samodzielna, niezależna od pomocy innych: „Pies jest mi potrzebny do pomocy w ubieraniu się (...) Guliwer pomoże mi zdjać buty i spodnie, podniesie przedmiot, który spadł... To uniezależnia od innych ludzi, podnosi moje poczucie własnej wartości" ${ }^{\prime 59}$. Z kolei Magda Biegańska, bohaterka artykułu „W snach ciągle chodzę", może być wzorem dla innych, mimo iż doświadczyła trudności, momentów zwątpienia (rozwód, nadopiekuńczość rodziny ograniczająca jej samodzielność), co jednak nie przeszkodziło jej w przełamywaniu kolejnych barier (mobilizacja po obozie dla osób na wózkach, zrobienie prawa jazdy, samodzielne zamieszkanie, podjęcie pracy, założenie stowarzyszenia, prowadzenie zajęć sportowych dla dzieci poruszających się na wózkach).

O wiele częstszym motywem jest jednak ukazanie bierności i bezradności osób niepełnosprawnych: w reportażu „Matki z gorszym mózgiem” osoby z niepełnosprawnością intelektualną zostały wręcz przedstawione jako niesamodzielne życiowo

$$
\begin{aligned}
& { }_{58} \text { "Zapomoga na Pompego". } \\
& { }^{58} \text {,"W snach ciaggle chodzę". } \\
& 59 \text { "Pan na smyczy". }
\end{aligned}
$$

(,W domu panuje nieopisany brud. Narobili zaległości w opłatach. Nie wiadomo czy mają co jeść"), bezwolne, wykorzystywane („Po jej śmierci krewni zabrali Agacie mieszkacie, jak to zwykle bywa"), padające ofiarami oszustw ${ }^{60}$, postępujące nieracjonalnie, infantylnie (,Renty albo pensje wydają od razu na coś, co im się podoba”), osoby, „którym trzeba niańki”, a bez opieki osób sprawnych są zagrożone zejściem „na społeczne dno”.

Dzieci niepełnosprawne, szczególnie wychowankowie ośrodków, często przedstawiane były jako nieprzystosowane do normalnego życia (wychowanka ośrodka Monika, która „nie umie się bawić, a umie mówić jak dorosła”, nie wie, „,co to sos z oliwkami; nigdy nie jadła kremówek"61, dzieci poruszające się na wózku, które „nie wychodzą, bo nie jeżdżą samochodem ani komunikacją miejską ${ }^{\prime \prime 2}$, absolwenci szkół specjalnych dla osób niesłyszących, którzy nie są przygotowani „do życia wśród słyszących, co jest jednoznaczne $z$ egzystowaniem poza społecznym nawiasem" $\left.{ }^{\prime \prime 3}\right)$.

Warto zauważyć, iż osoby niepełnosprawne będące bohaterami tekstów pokazane są w bardzo różnorodnych rolach społecznych. Najczęściej pojawia się rola pacjenta (bardzo często $\mathrm{w}$ ten sposób przedstawiane są dzieci, czasem przedstawiane jako „przypadki” $\left.{ }^{\prime \prime 4}\right)$, ale niemal równie często rola pracownika czy ucznia/studenta. W kilku tekstach

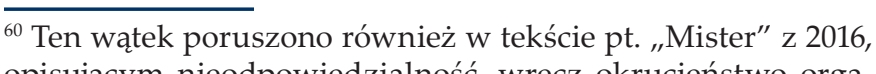
opisującym nieodpowiedzialność, wręcz okrucieństwo organizatorów konkursu, którzy rozbudzili w kandydatach pragnienia, a potem uniemożliwili ich realizacje.

"1 "Życie za życie".

62 "W snach ciagle chodzę".

63 "Głuche słowa".

${ }^{64}$, ,Życie poza życiem". osoby niepełnosprawne są przedstawiane $\mathrm{w}$ roli małżonka/partnera, rodzica, podopiecznego ośrodka, osoby uprawiającej sport, trenera, artysty, zdarzają się też pojedyncze przykłady takich ról jak: przyjaciel, współlokator, rencista, emeryt, siostra/ brat, ministrant, bezrobotny, społecznik, więzień. Przedstawiona różnorodność ról społecznych pozwala uniknać wyrwania osób niepełnosprawnych z ich społecznego kontekstu i jednowymiarowego pokazywania ich wyłącznie jako pacjentów czy podopiecznych ośrodków (Ruść 2007: 137).

\section{Seksualność i życie rodzinne}

Kilka tekstów odnosi się do macierzyństwa, seksualności oraz zawierania małżeństw przez osoby niepełnosprawne. Kwestia ta, w odniesieniu do osób z niepełnosprawnością intelektualną, została najbardziej rozwinięta w reportażu „Matki z gorszym mózgiem” z 1997 roku. Z jednej strony można tam odnaleźć fragmenty odnoszące się przychylnie do tego zjawiska, na przykład „Matka upośledzonej dziewczyny zauważyła, że odkąd wyszła za mąż, otworzyła się na ludzi, szybciej się rozwija, i widać, że jest szczęśliwa”, z drugiej strony wymowa artykułu jest dośćjednoznaczna: „Teresa Dłuska ma bez wątpienia rację: nie można pozwolić na reprodukcję nieszczęścia". Podobny wątek - braku akceptacji społecznej dla związków i bliskości osób niepełnosprawnych - pojawia się w reportażu z tego samego roku pod tytułem „Teatr albo nic": „W grupie są dwie pary i, jak twierdzi Elżbieta Szadura, ich problemy nie różnią się od problemów ich rówieśników (...) Tego typu związki nie są jednak dobrze postrzegane". W reportażu „Mały szuka nieba” z 2007 roku pojawiła się kwestia trudności w aktywności seksualnej, na 
przykład „Bała się, uciekała, gdy siedzieli na łóżku, a on wyciągał szyję w kierunku jej ust". Jednocześnie bohaterowie tego fotoreportażu to osoby spełnione $\mathrm{w}$ życiu uczuciowym i rodzinnym.

Ważną rolę w życiu osób niepełnosprawnych przedstawionych $w$ analizowanych tekstach pełnią rodzice: walczą o zdrowie i sprawność swoich dzieci, nieraz podporządkowując temu celowi całe swoje życie ${ }^{65}$, gotowi na wszystko (,Jest kilka matek, które pracują za granicą na ulicy. Bo nie ma upokorzenia, którego by nie warto znieść żeby ratować dziecko $\left.{ }^{\prime \prime 66}\right)$, niejednokrotnie są to osoby niebędące biologicznymi rodzicami ${ }^{67}$. Niechciane, porzucone dzieci niepełnosprawne rozkwitają pod wpływem miłości w specjalistycznych rodzinach zastępczych: „Gabrysia, oczko w głowie męża Renaty, ma dziś 9 lat. Miała być w najlepszym wypadku roślinką, a biega, że trudno za nią nadążyć'”68.

Rodzice pełnią także ważną rolę w życiu dorosłych osób niepełnosprawnych: „I samotni, i zamężni, funkcjonują nie najgorzej póki żyją rodzi$\mathrm{ce}^{\prime \prime 69}$. Czasem jednak ich zachowanie nosi znamiona nadopiekuńczości i uzależnienia od siebie: „Pojawił się Jan i mama rozwinęła nad nim parasol ze swojego życia; mama i Jan od zawsze byli jak jedna osoba"70; ,,dziewczyna, lat 16, nigdy nic sama nie robiła, we wszystkim wyręczali ją rodzi-

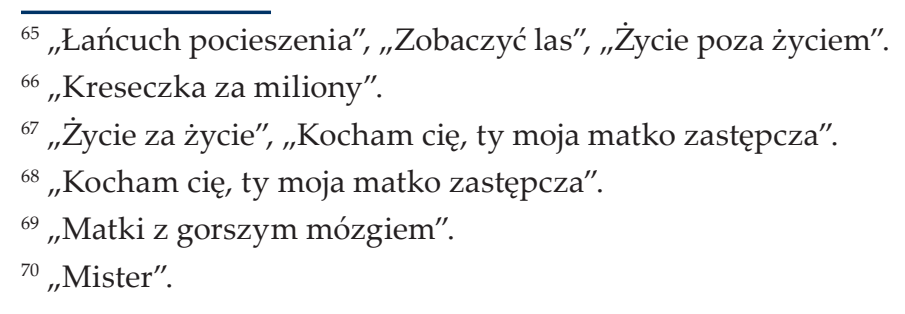

$\mathrm{ce}^{\prime \prime 71} . \mathrm{Z}$ drugiej strony pokazani są także rodzice niewierzący w możliwości swoich niepełnosprawnych dzieci: „Dla wielu z nich (szczególnie ojców) (...) dopiero wtedy dociera, że dziecko niepełnosprawne też coś potrafi" ${ }^{\prime 2}$, wstydzący się ich („Rodzice dzieci niesłyszących, spętani wstydem, zwlekają z założeniem dziecku aparatu. Bo to styg mat" $)^{73}$ czy też niemogący lub niechcący się nimi zajmować $^{74}$.

\section{Relacje osób niepełnosprawnych \\ $\mathrm{z}$ otoczeniem}

Często pojawiającym się wątkiem, niezależnie od analizowanego roku, jest izolacja społeczna osób niepełnosprawnych („,wózkowicze po zakończeniu obowiązkowej nauki trafiają do swoich pokojów jak do więzień. Nieraz na zawsze $\left.{ }^{\prime 75}\right)$ i niezrozumienie ze strony otoczenia (,mimo rewolucji w leczeniu nie nastąpiła rewolucja w ludzkiej mentalności. $\mathrm{Na}$ samą nazwę hemofilia (...) ludziom nieobeznanym z nią cierpnie skóra"76). To niezrozumienie wynika czasem także z nieznajomości osób niepełnosprawnych i ich potrzeb: „Niepełnosprawni nie uczą się z nami, nie pracują. Nie widzi się ich na ulicach, nie korzystają ze sklepów, miejskiej komunikacji, kina, teatrów, nie jeżdżą na wakacje, tkwią w domach, wstydliwie zamknięci przez rodziny"77. Pojawia się także kwestia wzbudzania niezdrowego

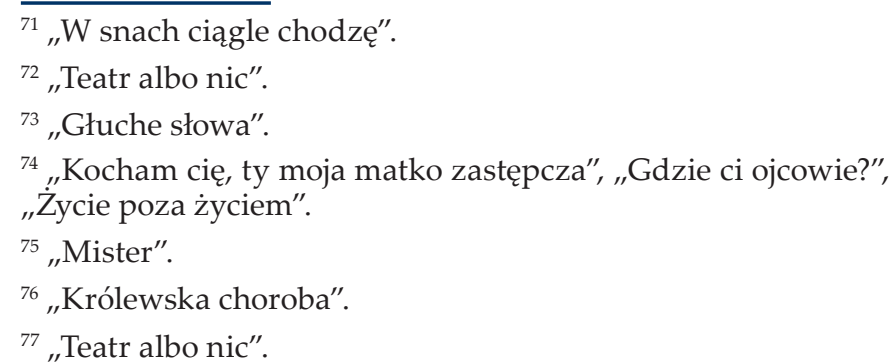

zainteresowania i zdziwienia swoim wyglądem („Takie coś przyciąga wzrok; mali z papierosem w ustach są dla dzieci atrakcją ${ }^{\prime 78}$ ).

Bohater reportażu „Prawie kino” krytycznie odnosi się do „pozornej tolerancji", która pozwala traktować osoby niepełnosprawne „z modną poprawnością, czyli z zupełną obojętnością". Wątek ten pojawia się też w fotoreportażu „Mały szuka nieba”: "Duzi są wyrozumiali, w końcu oglądają w telewizji reklamy społeczne o sprawnych inaczej”; „Duzi zatrudnili Włodka w firmie Hop jako informatyka, za co są dotacje. Tacy jak on nadają się do pracy w tzw. punktach niewidocznych, żeby nie narażać klientów na kontakt".

Czasem pojawia się również nietolerancja i dyskryminacja ze strony ludzi sprawnych: „Dzieci bywają okrutne, wyśmiewają, wytykają palcami (...) patrzcie to ta liliputka (...) nie ma przyjaciół, nie ma chłopaka, nie jest zapraszana na prywatki"79; „W szkole dzieci mówiły do mnie: Ty jesteś głucha. Robiło mi się przykro. Głucha to nic nie rozumie, nie myśli tak jak oni”80; „,w liceum mówili, że wygląda jak świnia" ${ }^{81}$.

Artykuły dotyczące niepełnosprawnych dzieci wskazuja na kwestię traktowania ich przez społeczeństwo jak ciężar. $\mathrm{W}$ artykule pod tytułem „Łańcuch pocieszenia” z 1997 roku zacytowano kilka wypowiedzi, z jakimi spotkali się rodzice dzieci z porażeniem mózgowym: „Postara się pani

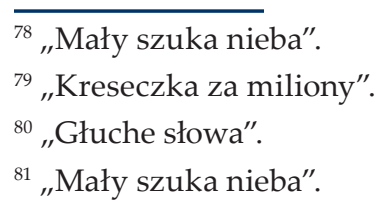

o nowe”; „Czy na pewno chce pani takie dziecko?"; „Dla nas takie dziecko warte jest 20-30\%. Nigdy nie będzie normalne".

Aktywność społeczna osób niepełnosprawnych ograniczana jest przez wstyd, wycofanie („Wstydzą się siebie, swojej niepełnosprawności i małej wiedzy o tym co wolno, a czego nie wolno"). Niektóre osoby niepełnosprawne mają trudności $\mathbf{w}$ akceptacji własnej odmienności fizycznej, na przykład „Wydaje mi się, że zawsze będę się uważała za gorszą kobietę niż te chodzące. Zawsze będę mieć kompleksy jakie'́" ${ }^{\prime \prime 2}$; "Ciało to jest ich ogromny problem. Oni siebie nie lubią" ${ }^{\prime 33}$, "Dziewczynki za nic nie chcą być do gazety fotografowane ${ }^{\prime \prime 84}$; „Łukasz to obiekt niedokończony. Chciałby jeszcze wydłużyć ręce, żeby móc tak objąć Agnieszkę caluteńką"85.

\section{Analiza warstwy językowej}

Stosunek autora tekstu do osób niepełnosprawnych może się ujawniać $\mathrm{w}$ doborze stosowanych przez niego określeń dotyczących niepełnosprawności, co wpływa także na zamierzone oddziaływanie i postawy odbiorcy $\mathrm{w}$ stosunku do opisywanego zagadnienia (Ruść2 007: 141). Od prasy opiniotwórczej można oczekiwać, iż będzie ona prezentować wyważony język i starać się unikać określeń przestarzałych czy pejoratywnych, a starać się promować język neutralny i podążać za obowiązującymi trendami w tym zakresie. Omawiany materiał został więc poddany analizie językowej, by przekonać

$$
\begin{aligned}
& { }_{82} \text {,W snach ciaggle chodzę". } \\
& 83 \text { "Teatr albo nic". } \\
& { }^{84} \text {,"Kreseczka za miliony". } \\
& { }^{85} \text { "Mały szuka nieba". }
\end{aligned}
$$


się, jakiego języka używano w stosunku do osób niepełnosprawnych oraz czy można wychwycić pewne tendencje i zmiany na przestrzeni analizowanych 20 lat.

Obecnie za określenia neutralne uważa się sformułowania niepetnosprawność, osoby niepetnosprawne lub też, coraz częściej stosowane, osoby z niepetnosprawnościa(-ami) (Galasiński 2013). Odchodzi się jednocześnie od przestarzałych określeń typu kaleka/kalectwo, inwalida/inwalidztwo, upośledzony/upośledzony umystowo, niedorozwinięty, dziecko specjalnej troski. Wszystkie z wyżej wymienionych określeń można jednak spotkać $\mathrm{w}$ analizowanych tekstach - przede wszystkim tych z 1997"6, rzadziej z 2007 roku $^{87}$. O istotności używanej terminologii może świadczyć wypowiedź Marii, kierowniczki warsztatów teatralnych, bohaterki fotoreportażu „Teatr albo nic" z 1997 roku, która nie lubi określenia „upośledzenie umysłowe”, „bo ono stygmatyzuje" ${ }^{\text {"88 }}$. Związek używanych określeń z postawami wobec osób niepetnosprawnych ilustruje także wypowiedź Zbigniewa Kowerczyka, bohatera reportażu „Prawie kino” z 2007 roku: „Można też nazywać niewidomych

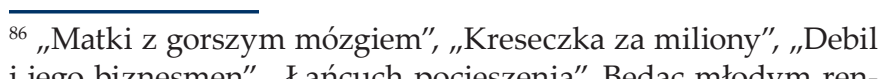
i jego biznesmen", , Łańcuch pocieszenia", Będąc młodym ren-
cistą". Użycie pojecia inwalida/inwalidztwo w tekstach z 1997 cistą" Uzycie pojęcia inwalida/inwalidztwo w tekstach z 1997
r. może być jeszcze zrozumiale - pojęcie inwalidztwa zostało zastapione pojęciem "niezdolność do pracy" dopiero Ustawą $\mathrm{z}$ dnia 28 czerwca 1996 roku o zmianie niektórych ustaw o zaopatrzeniu emerytalnym i ubezpieczeniu społecznym (Dz.U. 1996, Nr 100, poz. 461), która weszła w życie we wrześniu 1997 r. 87 "Żyrafa na ośmiu nogach", ,,Królewska choroba”, „Zapomoga na Pompego", ,Pan na smyczy".

${ }^{88} \mathrm{~W} 2015$ r. doszło nawet do zmiany nazwy stowarzyszenia działającego od $1991 \mathrm{r}$. na rzecz osób z niepełnosprawnością intelektualna - z Polskiego Stowarzyszenia na Rzecz Osób rzecz Osób z Niepełnosprawnością Intelektualną. Zmiana miała na celu przyczynienie się do upowszechniania modelu społecznego postrzegania niepełnosprawności - zob. Janocha 2015. «widzącymi inaczej» $\mathrm{i}$ traktować z modną poprawnością, czyli z zupełną obojętnością".

Artykuły publikowane w 1997 roku, w porównaniu z tymi, które ukazały się w roku 2007 oraz 2016, przesycone są określeniami i sformułowaniami pejoratywnymi, obraźliwymi, lekceważącymi i stygmatyzującymi w odniesieniu do osób niepełnosprawnych. Reportaże pod tytułem „Matki z gorszym mózgiem”, „Kreseczka za miliony” oraz recenzja "Debil i jego biznesmen” szokują wręcz, z dzisiejszego punktu widzenia, nagromadzeniem tak dużej liczby określeń nacechowanych negatywnie. Przykłady: „reprodukcja nieszczęścia” w odniesieniu do posiadania przez osoby niepełnosprawnie intelektualnie potomstwa; „matki z gorszym mózgiem" w odniesieniu do kobiet niepełnosprawnych, które rodzą dzieci; "uszkodzone dzieci”" ${ }^{\prime \prime}$, „,bezpłciowe twory". Recenzja „Debil i jego biznesmen" epatuje z kolei pojęciami i sformułowaniami, które dziś uznawane są powszechnie za niepoprawne obyczajowo, w tym: „nienormalny", ,"debil”, „ćwierćczłowiek”, „wariat”, "głupek”, „ludzki balast", ,"bezwładny paralityk", „poszkodowany mentalnie", ,ofiara wrodzonego mongolizmu". W reportażu na temat dziewczynek z zespołem Turnera odnajdziemy naturalistyczne opisy ich wyglądu, skupiające się na brzydocie: „,wiecznie stare dziewczynki”, „płaskie i nieforemne”, „I ich córka będzie małą, bezpiersiastą (...) nieforemną kobietą-dzieckiem" ${ }^{\prime \prime 9}$. Reportaż przesycony jest też określeniami podkreślającymi tragizm sytuacji: „życie marnej kategorii”, „żebranie o pomoc", „wyrok". W nowszych tekstach

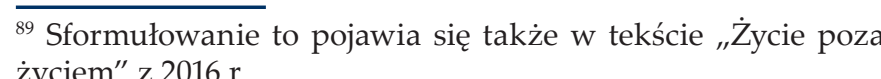
życiem" z 2016 r.

90 "Kreseczka za miliony". (z 2007 i 2016 roku) $)^{91}$ pojawiają się natomiast określenia nacechowane emocjonalnie, typu „chory na...", "cierpiący na..."

Obecnie unika się także stosowania określeń przymiotnikowych $\mathrm{w}$ funkcji rzeczownikowej (niepełnosprawni, upośledzeni, chorzy), argumentując, że pozbawiają one opisywane osoby podmiotowości i sugerują patrzenie na daną osobę jednowymiarowo, jedynie przez pryzmat jej niepełnosprawności czy choroby (Ruść 2007). Tego typu określenia pojawiały się, zazwyczaj sporadycznie, $w$ tekstach $\mathrm{z}$ wszystkich analizowanych lat, choć ich największe nagromadzenie znalazło się w tekstach: „Matki z gorszym mózgiem” oraz „Żyrafa na ośmiu nogach".

Wśród artykułów z 2007 roku tylko jeden reportaż pod tytułem „Mały szuka nieba” zawiera pejoratywne sformułowania jak "liliputy" i „,karzel”, a język reportażu jest naturalistyczny, brutalny, dosadny, na przykład „W Stalowej Woli mijał starego zegarmistrza, który dźwigając dużą głowę, osadzoną nisko na puklerzowatym korpusie z wysuniętym zadem, człapał do zakładu” albo „W kawiarni popija kawę dwójka małych, zdeformowanych, niemodnych". Pozostałe teksty cechowały się językiem raczej neutralnym, bez pejoratywnych określeń, nieraz dominował język naukowy, rzeczowy. W reportażach „Żyrafa na ośmiu nogach” oraz „Prawie kino” wystąpiły humorystyczne, ale ciepłe i przyjazne opisy osób niepełnosprawnych i ich zachowań

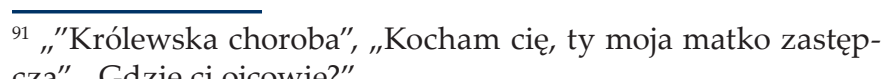
cza", ,Gdzie ci ojcowie?".

${ }^{92}$ Obecnie zastępuje się je neutralnym „,osoba z..." - takie określenia również pojawiały się w ww. tekstach. Por. Cohen (b.d.).
Zdecydowana większość artykułów z 2016 roku nie zawierała określeń nacechowanych negatywnymi emocjami. Teksty te charakteryzują się dużą „poprawnością" obyczajową; w żadnym z analizowanych tekstów nie użyto sformułowań szokujących, dyskredytujących czy pejoratywnych.

\section{Wizerunek osób niepełnosprawnych $\mathrm{w}$ analizowanych artykułach}

W analizowanych tekstach można odnaleźć przykłady wszystkich wyróżnionych przez Clogstona i Haller modeli dotyczących sposobów przedstawiania osób niepełnosprawnych $\mathrm{w}$ mediach ${ }^{93}$. Najczęściej występującym modelem był model medyczny - w tekstach takich jak między innymi „Łańcuch pocieszenia”, „Kreseczka za miliony”, „Życie poza życiem” czy "Głuche słowa” niepełnosprawność jest przedstawiona jako choroba, opisane są trudności związane z jej leczeniem i doprowadzaniem pacjenta do „normy”, pokazany „tragiczny los” osób niepełnosprawnych. $\mathrm{Z}$ drugiej strony teksty takie jak „Zobaczyć las" mimo że skupiają się na aspektach medycznych, mają także na celu poszerzenie wiedzy czytelników na temat określonego schorzenia czy niepełnosprawności, a także obalenie mitów i stereotypów z nimi związanych ${ }^{94}$.

W tekstach takich jak "Matki z gorszym mózgiem” czy „Życie poza życiem” można z kolei odnaleźć elementy modelu patologii społecznej - osoby niepełnosprawne zostały pokazane jako pokrzywdzone przez los, zależne od innych, niesamodzielne. ${ }_{93} \mathrm{~W}$ niektórych tekstach można było znaleźć elementy kilku
modeli.

${ }_{94}$ „Teatr albo nic", ,Królewska choroba”. 
Przedstawienie niepełnosprawności jako finansowego obciążenia dla społeczeństwa i biznesu (model biznesowy) dostrzec można w tekstach „Będąc młodym rencistą", „Każdy głos na wagę złota” (choć $\mathrm{w}$ tym tekście autor nie neguje pomocy osobom niepełnosprawnym, a jedynie krytykuje zwiększenie obciążeń dla przedsiębiorców: „Niepełnoprawnymi powinni opiekować się wszyscy, czyli państwo, a nie tylko ci, którzy potrafią lepiej od innych robić pieniądze").

W analizowanych tekstach odnaleźć można także progresywne modele przedstawiania osób niepełnosprawnych. Celem kilku z analizowanych tekstów było pokazanie, że osoby niepełnosprawne są "takie jak my” (w domyśle sprawni) czytelnicy (model pluralizmu kulturowego). Niepełnosprawni bohaterowie mają „zwyczajne” potrzeby - samodzielności, intymności, bliskości (jak zaznaczyła jedna z bohaterek tekstu „Teatr albo nic" z 1997 roku: „Oni zwyczajnie chcą miłości. Takiej najzwyklejszej na świecie"), pracy i czucia się potrzebnym ${ }^{95}$, uczestnictwa w kulturze masowej - choćby przez oglądanie filmów ${ }^{96}$. Mają także podobne problemy jak ich rówieśnicy: problemy uczuciowe („,mają nieporozumienia, kłócą się, przepraszają, są szczęśliwi lub dla odmiany cierpią ${ }^{\prime 97}$ ), rozpad związku ${ }^{98}$, problemy finansowe, nałogi ${ }^{99}$. Chęć przedstawienia życia osób niepełnosprawnych jako zwyczajnego i niewiele różniącego się od życia osób sprawnych widoczna jest szczególnie w fotoreportażu „Mały

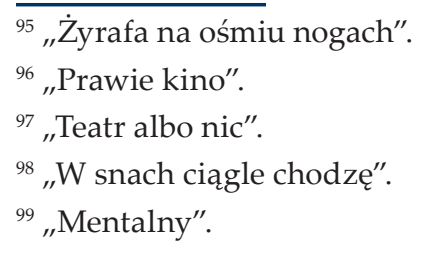

szuka nieba" z 2007 roku, który opisuje życie czterech par osób o niskim wzroście, powtarzając sformułowania: ,jest jak u longersów”; „,u małych jest jak u dużych"; „obecnie jest tuzinkowo"; „obecnie jest zwyczajnie". W artykule pod tytułem „Prawie kino" z 2007 roku niewidome i niedowidzące dzieci i młodzież przedstawione są jako podchodzące z dystansem i poczuciem humoru do swojej niepełnosprawności: „Jakby was teraz zobaczył ktoś obcy.. - mówi. - Pomyślałby, że biedne ślepaki nie zajarzyły, że się film skończył - pada odpowiedź z grona kinomanów. Śmieją się z tego obrazka" oraz jako nieużalające się nad sobą: „Żadne niewidome dziecko z ośrodka przenigdy nie żaliło się Zbyszkowi, że nie widzi". $Z$ drugiej strony w części tych tekstów znajdują się także elementy modelu "superkaleki" - przedstawienia osób niepełnosprawnych osiągających coś niezwykłego dla przeciętnego odbiorcy (jak bohater reportażu „Mentalny”, mistrz Polski w tenisie stołowym) czy też osiągających ",pomimo" swojej niepełnosprawności coś, co wydaje się być standardem w świecie osób pełnosprawnych (np. niewidomi uczniowie oglądający filmy z reportażu „Prawie kino”).

Model prawny widoczny jest w tekście „Udane niepowodzenia", który zawiera odniesienie do ratyfikacji przez Polskę konwencji ONZ o prawach osób niepełnosprawnych, przez co zobowiązała się ona do zapewnienia tym osobom pełnego i równego korzystania ze wszystkich praw człowieka i podstawowych wolności. W tekście „Zapomoga na Pompego" dominuje model praw mniejszości / praw obywatelskich - osoby z rzadkimi chorobami przedstawione są jako walczące o swoje prawa („Zdesperowani chcą poskarżyć się we władzach
Unii, wierząc, że dopiero te będą w stanie otworzyć oczy polskim władzom na problemy rzadkich chorób"). W kilku tekstach można odnaleźć elementy modelu konsumenckiego - osoby niepełnosprawne przedstawione zostały jako aktywne zawodowo, samodzielne, zarabiające i wydające pieniądze („Telechałupnicy", Żyrafa na ośmiu nogach”, „Mały szuka nieba”, ,"Teatr albo nic").

Analizując sposoby przedstawiania osób niepełnosprawnych w tygodniku „Polityka” w badanych latach, można zauważyć stopniowy wzrost liczby artykułów, w których dominują modele progresywne i równoczesny spadek liczby artykułów z dominującymi modelami tradycyjnymi.

\section{Zakończenie}

Wizerunek osób niepełnosprawnych kreowany przez media masowe to ważny, ale stosunkowo rzadko poruszany w polskiej debacie naukowej temat. Dlatego też zdecydowano się na jego analizę w oparciu o treści publikowane przez tygodnik opiniotwórczy „Polityka”. Badania wykazały, że najczęściej występującymi wątkami powtarzającymi się w wielu artykułach niezależnie od roku wydania były: pokazanie trudnej sytuacji osób niepełnosprawnych, koszty ekonomiczne i emocjonalne związane z niepełnosprawnością, trudności w relacjach osób niepełnosprawnych z otoczeniem, wątek miłości, partnerstwa, rodzicielstwa, potrzeb intymnych osób niepełnosprawnych, wątek wyizolowania społecznego, braku samoakceptacji osób niepełnosprawnych, niewydolność polityki społecznej i zdrowotnej, porównanie sytuacji osób niepełnosprawnych w Polsce i innych krajach oraz wartość, jaką dla osób niepełnosprawnych stanowi praca i aktywność społeczna. Zdziwić może dość słabe zainteresowanie tematyką aktywności zawodowej osób niepełnosprawnych, zwłaszcza że ostatnie 20 lat obfitowało w zmiany zarówno prawno-instytucjonalne, jak i świadomościowe w tym zakresie.

Opisane w artykule analizy pozwoliły na weryfikację tez postawionych na etapie konceptualizacji badań. Niewątpliwie można zauważyć potwierdzenie prawdziwości tezy uzupełniającej badania: znacząco zmienił się język, jakim opisuje się osoby niepełnosprawne i zjawisko niepełnosprawności w tygodniku „Polityka” na przestrzeni 20 lat. W analizowanym okresie można także zauważyć malejącą liczbę artykułów o pejoratywnym wydźwięku, przedstawiających osoby niepełnosprawne $\mathrm{w}$ negatywnie nacechowanym, niekorzystnym świetle. Przeprowadzone analizy pozwalają także na potwierdzenie tezy przewodniej badania - na przestrzeni lat 1997-2016 wizerunek osób niepełnosprawnych kreowany przez tygodnik „,Polityka” ewoluował od modeli bardziej „tradycyjnych" do modeli „progresywnych". Mimo to osoby te nadal często przedstawiane są w roli "ofiary” - losu, systemu, niekorzystnych rozwiązań, braku zrozumienia i tolerancji. Niepełnosprawni bohaterowie tekstów bywają zepchnięci na margines życia społecznego i zawodowego, niekiedy toczą dramatyczne walki o środki na leczenie, spotykają się z nietolerancją, traktuje się ich jak ciężar i potencjalnych lub aktualnych klientów pomocy społecznej. W celu wywołania określonego efektu wzbudzenia współczucia, litości, oburzenia - następuje nadmierna koncentracja na niepełnej sprawności, nierzadko epatuje się naturalistycznymi opisami i podkreśla ograniczenia. 
Z drugiej strony można przypuszczać, że taki sposób pokazywania osób niepełnosprawnych w opiniotwórczym tygodniku ma na celu wywołanie reakcji idących dalej niż chwilowe współczucie czy wzruszenie - ma skłonić do refleksji, niezgody na przedstawioną sytuację i podjęcia działań służących jej zmianie. Widoczne są także pozytywne tendencje - wiele analizowanych tekstów starało się pokazać osoby niepełnosprawne nie tylko jako te potrzebujące wsparcia finansowego, rodzinnego i instytucjonalnego, lecz także dążące do samodzielnego funkcjonowania. Czytelnik dowiaduje się, z jakimi trudnościami w relacjach społecznych, zawodowych i czysto międzyludzkich osoba niepełnosprawna musi borykać się na co dzień i jak wiele barier musi pokonać, aby żyć aktywnie, ale pomimo tego może wieść szczęśliwe życie rodzinne, pomagać innym, osiągać sukcesy, kształcić się, realizować swe pasje, marzenia i talenty czy po prostu codzienną pracą zarabiać na życie. „Polityka” przedstawia więc czytelnikom osoby niepełnosprawne zarówno przez pryzmat ich ograniczeń sprawności, jak i poprzez talenty, osiągnięcia i kompetencje. Docenić należy także unikanie stereotypu "superkaleki” $\mathrm{w}$ przedstawianiu osób niepełnosprawnych (tragicznych bohaterów, którzy pomimo przeciwności losu osiągają sukces), a także pojawianie się tekstów

\section{Bibliografia}

Anusiewicz Janusz, Bartmiński Jerzy, red., (1998) Stereotyp jako przedmiot lingwistyki: teoria, metodologia, analizy empiryczne. Wrocław: Towarzystwo Przyjaciół Polonistyki Wrocławskiej. o charakterze informacyjnym, starających się rozszerzyć wiedzę czytelników na temat różnych typów niepełnosprawności, przedstawiających i proponujących nowe rozwiązania.

Wydaje się więc, że mimo iż sygnalizowanie problemów i pokazywanie obszarów funkcjonowania osób niepełnosprawnych, które wymagają zmiany, jest niewątpliwie konieczne, prasa opiniotwórcza powinna także wzmacniać pozytywny przekaz - częściej pokazywać osoby niepełnosprawne jako aktywnych członków społeczeństwa, w różnych kontekstach, bez uwypuklania ograniczeń sprawności. Debata nad problemami osób niepełnosprawnych nie powinna być fragmentaryczna i ograniczać się do wybranych tematów, na przykład braku dofinansowania na leczenie określonych schorzeń - dobrym przykładem bardziej wszechstronnego podejścia jest tekst „Udane niepowodzenia” z 2016 roku, nie tylko diagnozujący problemy i zaniechania polityki wobec niepełnosprawności, ale także proponujący konkretne rozwiązania. Do debaty nad aktualnymi problemami powinno się także włączyć same osoby niepełnosprawne - nie tylko jako opisywane "przypadki”, ale jako przedstawicieli środowiska i ekspertów od opisywanych problemów.

Baran Stanley J., Davis Dennis K. (2007) Teorie komunikowani masowego. Kraków: Wydawnictwo Uniwersytetu Jagiellońskiego.

Barnes Collin (1992) Disabling Imagery and the Media. An Exploration of the Principles for Media Representations of Disabled People.
The First in a Series of Reports. Halifax: Ryburn Publishing, The British Council of Organisations of Disabled People.

CBOS (2007) Postawy wobec osób niepetnosprawnych. Komunikat z badań. Warszawa.

Clogston John. S. (1990) Disability coverage in 16 newspapers. Louisville, KY: Avocado Press.

Clogston John. S. (1993) Changes in coverage patterns of disability issues in three major American newspapers, 1976-1991. Paper presented to the Association of Education in Journalism and Mass Communication. Kansas City, MI

Cohen Judy (b.d.) Praktyczny poradnik savoir-vivre wobec osób niepetnosprawnych. Tłumaczenie na zlecenie MPiPS [dostęp 29 października 2017 r.]. Dostępny w Internecie: http://www. niepelnosprawni.gov.pl/dobre-praktyki/.

Falkowski Andrzej, Tyszka Tadeusz (2006) Psychologia zachowań konsumenckich. Gdańsk: Gdańskie Wydawnictwo Pedagogiczne.

Galasiński Dariusz (2013) Osoby niepetnosprawne czy z niepetnosprawunościa? „Niepełnosprawność - zagadnienia, problemy, rozwiązania", nr IV(9) s. 3-6.

Goban-Klas Tomasz (2008) Media i komunikowanie masowe. Teorie i analizy prasy, radia, telewizji i Internetu. Warszawa: Wydawnictwo Naukowe PWN.

Haller Beth (1999) How the News Frames Disability: Print Media Coverage of the Americans with Disabilities Act. „Research in Social Science and Disability", vol. 1, s. 55-83.

Haller Beth (2000) If they limp, they lead? News representations and the hierarchy of disability images [w:] Dawn Braithwaite, Teri Thompson, eds., Handbook of communication and people with disabilities: Research and application. Mahwah, New Jersey: Lawrence Erlbaum Associates, s. 273-288

Janocha Joanna (2015) Ja rodzic, ja cztonek Polskiego Stowarzyszenia na rzecz Osób z Niepetnosprawnościa Intelektualna. „Społeczeństwo dla wszystkich", nr 4(56), s. 2-3 [dostęp 29 października 2017 r.]. Dostępny w Internecie: http://psouu.org.pl/sites/ default/files/publikacje/SdW_4-2015_do_INTERNETU_0.pdf .
Kossowska Małgorzata (2006) O motywach sprzyjajacych vs. przeciwdziatajacych powstawaniu uprzedzeń. „Psychologia Społeczna", nr 2 (2), s.13-22.

Niedbalski Jakub (2015) Sport osób niepetnosprawnych w przekazie i dyskursie medialnym w Polsce. „Przegląd Socjologii Jakościowej", t. 11, nr 2, s. 130-159.

Piber-Dąbrowska Kinga, Sędek Grzegorz (2006) Spostrzeganic bez uprzedzeń $i$ stereotypów - zarys problematyki. „Psychologia Społeczna", $\operatorname{nr} 2$ (2), s.7-12.

Rozmus Paweł (2012) Odmienność odbita w ekranach. Konstruowanie obrazu niepetnosprawności poprzez kampanie spoteczne i telewizje. „Palimpsest", nr 2, s. 103-118.

Ruść Iwona (2007) Wizerunek osób z ograniczona sprawnościa w mediach [w:] Anna Brzezińska, Zbigniew Woźniak, Konrad Maj, red., Osoby z ograniczona sprawnościa na rynku pracy. Warszawa: Wyd. SWPS „Academica”, s. 131-148.

Stownik Oxford Wordpower (2002). Oxford: Oxford University Press.

Sobol Elżbieta, red. (1996) Stownik wuyrazów obcych. Warszawa Wydawnictwo Naukowe PWN.

Tabernacka Magdalena, Szadok-Bratuń, red. (2012) Public relations $w$ sferze publicznej. Wizerunek $i$ komunikacja. Warszawa: Wolters Kluwer.

Tworzydło Dariusz, Olędzki Jerzy, Trochimiuk Paweł, red. (2009) Leksykon PR. Rzeszów: Newsline.

Ustawa z dnia 28 czerwca 1996 roku o zmianie niektórych ustaw o zaopatrzeniu emerytalnym i ubezpieczeniu społecznym, Dz.U. 1996, Nr 100, poz. 461.

Ustawa z dnia 27 sierpnia 1997 roku o rehabilitacji zawodowe i społecznej oraz zatrudnianiu osób niepełnosprawnych, Dz.U. 2011, Nr 127, poz. 721 z późn. zm.

Ustawa z dnia 24 sierpnia 2007 r. o zmianie ustawy - Kodeks pracy oraz niektórych innych ustaw, Dz.U. 2007 Nr 181, poz. 
Ustawa z dnia 4 listopada 2016 r. o wsparciu kobiet w ciąży i rodzin „Za życiem”, Dz.U. 2016, poz. 1860

\section{Analizowane artykuły}

Armatys Jarosław (2007) Gtuche stowa. „Polityka”, nr 2603 / 2007-05-12 s. 114-115

Cieśla Joanna (2016) Mentalny. „Polityka, nr 3063 / 2016-06-08, s. 38-39.

Gietka Edyta (2007) Życie za życie. „Polityka”, nr 2594 / 2007-0303 s. 32-35.

Gietka Edyta (2007) Mały szuka nieba. „Polityka”, nr 2624 / 2007$10-13$, s. 140-145.

Kałużyński Zygmunt (1997) Debil i jego biznesmen. „Polityka”, nr 25 (2094), s. 56-57.

Kołodziejczyk Marcin (2007) Prawie kino. „Polityka”, nr 2634 / 2007-12-22 s. 148-150.

Kołodziejczyk Marcin (2016) Mister. „Polityka”, nr 3065 / 201606-22, s. 38-39.

Kubicki Paweł (2016) Udane niepowodzenia. „Polityka”, nr 3087 / 2016-11-23, s. 38-39.

Leszczyńska Joanna (2016) Kocham cię, ty moja matko zastępcza. „Polityka”, nr 3048 / 2016-02-24, s. 100-105.

Pietkiewicz Barbara (1997) Kreseczka za miliony. „Polityka”, nr 31 (2100), s. 24-25.

Pietkiewicz Barbara (1997) Matki z gorszym mózziem. „Polityka”, nr 18 (2087), s. 30-32.

Pustkowski Marcin (2007) Zobaczyć las. „Polityka”, nr 2607 / 2007-06-09 s. 86-88.
Wojciszke Bogdan (2002) Człowiek wuśród ludzi. Zarys psychologii spotecznej. Warszawa: Wydawnictwo Naukowe Scholar.
Rzaż̇ewska Aleksandra (2007) Zyrafa na ośmiu nogach. „Polityka", nr 2604 / 2007-05-19, s. 124-129.

Socha Ryszarda (2016) W snach ciagle chodze. , ,Poradnik Psychologiczny Polityki", Tom 22. Dusza i ciało nr 5 / 2016-05-11) s. 82-83.

Socha Ryszarda (1997) Eańcuch pocieszenia. „Polityka”, nr 47 (2116), s. 25-26.

Socha Ryszarda (2007) Pan na smyczy. „Polityka”, nr 2596 / 2007 03-17, s. 108-113.

Socha Ryszarda (2007) Telechatupnicy., Polityka”, nr 2632 / 2007 $12-08$, s. 50-51.

Sowa Agnieszka (2016) Życie poza życiem. „Polityka”, nr 3085 2016-11-08, s. 22-25.

Turlej Elżbieta, [współpr.] Violetta Krasnowska (2016) Gdzie ci oicowie? „Polityka”, nr 3084 / 2016-11-02, s. 18-20.

Walewski Paweł JB (2007) Zapomoga na Pompego. „Polityka” nr 2621 / 2007-09-26, s. 108-110.

Walewski Pawel (2007) Królewska choroba. „Polityka”, nr 46 (2629) / 2007-11$17,5.96-97$.

Walewski Paweł (1997) Bẹdac młodym rencista. „Polityka”, nr 15 (2084) s. 94

Wróblewski Andrzej Krzysztof (1997) Każdy głos na wage ztota. „Polityka”, nr 37 (2106), s. 13.

Zielińska-Fazan Małgorzata (1997) Teatr albo nic. „Polityka”, nr 48 (2117), s. 102-104.

\section{Cytowanie}

Struck-Peregończyk Monika, Kurek-Ochmańska Olga (2018) Wizerunek osób niepetnosprawnych w polskiej prasie opiniotwórczej na przykładzie tygodnika "Polityka” w latach 1997-2016. „Przegląd Socjologii Jakościowej”, t. 14, nr 3, s. $48-71$ [dostęp dzień, miesiąc, rok]. Dostępny w Internecie: «www.przegladsocjologiijakosciowej.org. DOI: http://dx.doi.org/10.18778/1733-8069.14.3.04

\section{The Image of Disabled People in Polish Opinion-Forming Press Based on the Example of} "Polityka" Weekly Magazine between 1997 and 2016

Abstract: The aim of the article is to analyze the content of Polish opinion-forming weekly magazines (concentrating on the example of "Polityka") in regard to disability and disabled people. The paper attempts to outline the image of disabled people created by this magazine. The main categories considered in the analysis were: social and professional roles of the portrayed disabled people; an attempt to catalogue the subject matter of the articles; language used to describe disability and disabled people and the reference of topics discussed to the current events and trends. The article also looks at general trends in the representation of disabled people in mass media and gives an overview of different theoretical approaches to explaining the role of the media in creating attitudes towards different social groups.

Keywords: image, disability, press, media influence 